\title{
Acremolin, a stable natural product with an antiaromatic $1 H$-azirine moiety? A structural reorientation
}

\author{
Klaus Banert* \\ Organic Chemistry, Chemnitz University of Technology, Strasse der Nationen 62, 09111 Chemnitz, Germany
}

\section{ARTICLE INFO}

\section{Article history:}

Received

Received in revised form

Accepted

Available online

\section{ABSTRACT}

Recently, acremolin (4), a novel modified base, was isolated from a marine-derived fungus and claimed to possess a structure with a $1 H$-azirine moiety. It is shown now that the reported NMR data are not compatible with this antiaromatic heterocycle, which should be an extremely unstable compound. An isomeric, substituted $N^{2}, 3$-ethenoguanine is presented as a plausible alternative structure of acremolin that is consistent with all spectroscopic data. Thus, $1 H$-azirines keep their classification as very short-lived intermediates.

\section{Keywords: \\ Acremolin \\ Antiaromatic heterocycles \\ $N^{2}, 3$-Ethenoguanines \\ NMR spectroscopy \\ Structural corrigendum}

Strained compounds are of special interest because of their increased energy content and the enhanced reactivity, which frequently results from this. For $1 H$-azirines $\mathbf{1}$ and $2 H$-azirines $\mathbf{2}$, it is obvious that both types of heterocycles include considerable ring strain (Scheme 1). However, the properties of $\mathbf{1}$ and $\mathbf{2}$ are quite different. ${ }^{1}$ A great number of $2 \mathrm{H}$-azirines $\mathbf{2}$, especially those with $\mathrm{R}^{1} \neq \mathrm{H}$, were isolated and characterized by spectroscopic methods in solution or even by X-ray crystallographic structure determination. Although compounds of type 2 are highly reactive, the $2 \mathrm{H}$-azirine unit has been found in a few natural products. ${ }^{2}$ On the other hand, only five examples of short-lived $1 H$-azirines $\mathbf{3 a}, \mathbf{b}$ were photochemically generated and detected at very low temperatures by IR spectroscopy, which indicated absorptions in the region of $1867-1890 \mathrm{~cm}^{-1}$ attributed to $\mathrm{C}=\mathrm{C}$ valence vibration. ${ }^{3}$ Most probably, the push-pull substitution pattern of $\mathbf{3 a}, \mathbf{b}$ diminishes the antiaromatic character of the $1 H$-azirine structure and increases the relative stability. Thus, attempts to isolate or observe the parent compound ( 1 with $\mathrm{R}^{1}=\mathrm{R}^{2}=\mathrm{R}^{3}=\mathrm{H}$ ) by cycloaddition ${ }^{4}$ or cyclorevision ${ }^{5}$ approaches and by using argon-matrix isolation technique were unsuccessful and yielded unsubstituted $\mathbf{2}$ and other isomeric species. Elusive $1 H$-azirine intermediates were merely postulated in several other reactions, which finally led to $2 \mathrm{H}$-azirines, ${ }^{6}$ pyrroles, ${ }^{7}$ indoles, ${ }^{8}$ oxazoles, ${ }^{9}$ isoquinolines, ${ }^{10}$ ketenimines, ${ }^{11}$ nitriles, ${ }^{12}$ or anilines. ${ }^{13}$ Furthermore, many quantum chemical calculations, that analyzed the energy content, ${ }^{14}$ the molecular geometry, ${ }^{15}$ the nitrogen

* Tel.: + 49 37153131463; fax: + 4937153121229

E-mail address: klaus.banert@chemie.tu-chemnitz.de inversion barrier, ${ }^{16}$ the basicity, ${ }^{17}$ and the vibrational frequencies and IR intensities ${ }^{18}$ of the parent $1 H$-azirine $\mathbf{1}$, have been published. All experimental and theoretical results emphasize the properties of the antiaromatic heterocycles $\mathbf{1}$ as short-lived intermediates, which cannot be isolated at room temperature.

Recently, Shin et al. reported on the isolation of a novel modified base from the culture broth of the marine fungus Acremonium strictum. ${ }^{19}$ They called this compound acremolin and analyzed the white amorphous solid with the help of HRFAB-MS to get the molecular formula $\mathrm{C}_{11} \mathrm{H}_{13} \mathrm{~N}_{5} \mathrm{O}$. Moreover, IR and UV spectra were recorded, and ${ }^{1} \mathrm{H}$ NMR and ${ }^{13} \mathrm{C}$ NMR investigations including ${ }^{1} \mathrm{H}$ COSY, HSQC, and long-range HMBC methods were performed. This led to the surprising structure 4 (Figure 1). The authors emphasized that the presence of a $1 \mathrm{H}$-azirine moiety is unprecedented among natural products. ${ }^{19}$ However, such an antiaromatic heterocycle has never<smiles></smiles>

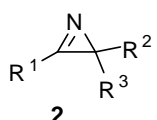

2<smiles>[R]C1=C([R])N1C#N</smiles>

3a,b

$$
\begin{aligned}
& \text { a } R^{1}=\mathrm{NPh}_{2}, \mathrm{R}^{2}=\mathrm{P}(\mathrm{O}) \mathrm{Ph}_{2} \\
& \text { b } \mathrm{R}^{1}=\mathrm{OMe}, \mathrm{O} i \mathrm{Pr}, \mathrm{OCHMeEt}, \\
& \text { OCHEt }, \mathrm{R}^{2}=\mathrm{H}
\end{aligned}
$$




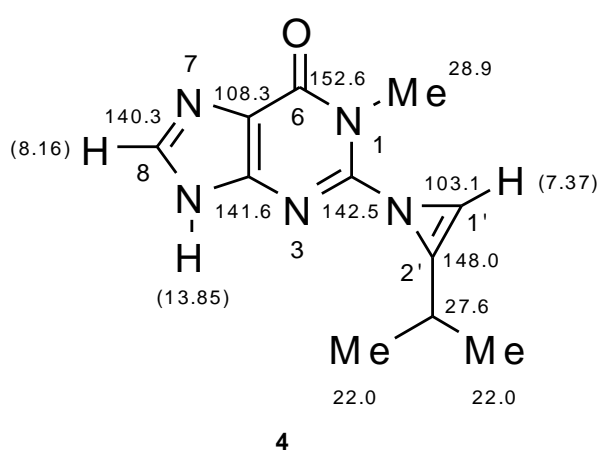

Figure 1. Structure 4, reported for acremolin in ref. ${ }^{19}$, and the assignment of the corresponding ${ }^{13} \mathrm{C} \mathrm{NMR}$ signals and some of the ${ }^{1} \mathrm{H}$ NMR signals $\left(\delta\right.$ values, DMSO $\left.-d_{6}\right)$.

been isolated as a pure compound or characterized in solution although this was tried many times. ${ }^{1}$

Some doubts about the structure $\mathbf{4}$ already resulted from the chemical shifts in the ${ }^{1} \mathrm{H}$ NMR and ${ }^{13} \mathrm{C}$ NMR spectra reported by Shin et al. ${ }^{19}$ The proton $\mathrm{H}-1$ ' was said to generate a signal with $\delta$ $=7.37$, which is within the typical region of aromatic compounds (Figure 1). ${ }^{20}$ But the antiaromatic properties of the $1 H$-azirine moiety should induce a shielding effect for the perimeter proton $\left(\mathrm{H}-1^{\prime}\right)$ and an upfield shift for the corresponding ${ }^{1} \mathrm{H}$ NMR signal. ${ }^{21}$ Furthermore, the great value of $\Delta \delta\left(\mathrm{C}-2^{\prime} / \mathrm{C}-1^{\prime}\right)=44.9$ ppm cannot be explained by the usual $\alpha$-effect of an isopropyl group on the adjacent olefinic carbon atom $(+20.3 \mathrm{ppm})$ and the corresponding $\beta$-effect $(-11.5 \mathrm{ppm}){ }^{22}$ because the sum only reaches a value of $31.8 \mathrm{ppm}$. Instead of $\mathbf{4}$, an alternative structure, in which C-1' and C-2' are intrinsically (even without isopropyl group) different, should be discussed. However, the strongest argument against the structure $\mathbf{4}$ is the isolation of acremolin at room temperature, which is absolutely incompatible with an antiaromatic $1 H$-azirine moiety. ${ }^{1,3-18}$
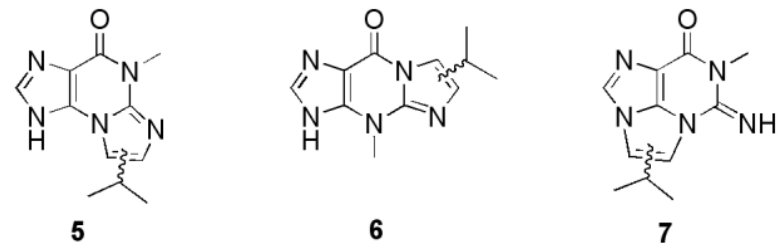

Scheme 2. Structures of isomeric ethenoguanines with the formula $\mathrm{C}_{11} \mathrm{H}_{13} \mathrm{NO}$.

When the three-membered ring of $\mathbf{4}$ is omitted and a second fused five-membered cyclic system is introduced, the isomeric etheno-bridged guanines 5, 6, and 7 can result (Scheme 2). Whereas 6 and 7 are not compatible with ${ }^{1} \mathrm{H}$ COSY or HMBC<smiles></smiles>

8

Figure 2. ${ }^{13} \mathrm{C}$ NMR and ${ }^{1} \mathrm{H}$ NMR data of $1 H$-imidazo[2,1-b]purine-4 $(5 H)$-one $(\mathbf{8})$ reported in ref. ${ }^{23 \mathrm{a}, \mathrm{d}}$ ( $\delta$ values, DMSO- $\left.d_{6}\right)$. experiments reported ${ }^{19}$ by Shin et al., both regioisomers of $\mathbf{5}$ are plausible candidates for a revised structure of acremolin. Fortunately, the complete ${ }^{1} \mathrm{H}$ NMR and ${ }^{13} \mathrm{C}$ NMR data of compound $\mathbf{8}$ were published (Figure 2). ${ }^{23}$ These data can now be utilized to calculate the ${ }^{1} \mathrm{H}$ and ${ }^{13} \mathrm{C}$ NMR $\delta$ values of $\mathbf{5 a}$ and $\mathbf{5 b}$ (Figure 3). The additional methyl group at N-5 should induce small upfield shifts for the four carbon atoms of the sixmembered ring. This assumption is based on ${ }^{13} \mathrm{C}$ NMR studies ${ }^{24}$ with uracil and 3-methyluracil, which show little shielding effects due to the methyl group ( $\Delta \delta=0.4-3.4 \mathrm{ppm})$. In the case of 2-thiouracil and 3-methyl-2-thiouracil, the changes of the chemical shifts are even smaller $(\Delta \delta=0.5-1.5 \mathrm{ppm}){ }^{24}$

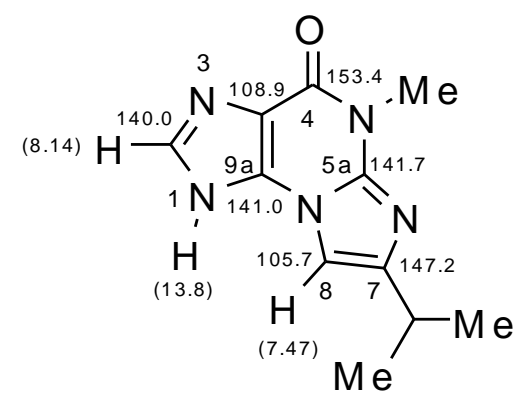

$5 a$

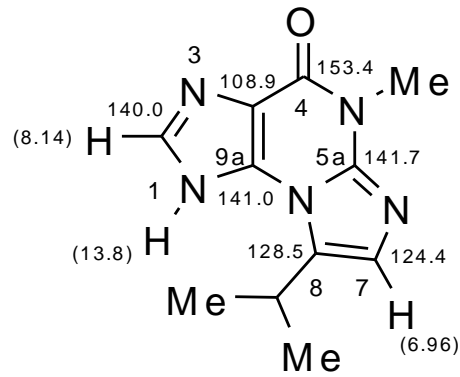

$5 \mathrm{~b}$

Figure 3. Calculated ${ }^{13} \mathrm{C}$ NMR and ${ }^{1} \mathrm{H}$ NMR data of $\mathbf{5 a}$ and $\mathbf{5 b}$ ( $\delta$ values, DMSO $-d_{6}$ ) based on the corresponding data of 8 and increments for the additional methyl group at $\mathrm{N}-5$ and the isopropyl group at $\mathrm{C}-7$ or $\mathrm{C}-8$.

Thus, upfield shifts of $\Delta \delta=1.0 \mathrm{ppm}$ due to the additional methyl group were included when the $\delta$ values of C-3a, C-4, C$5 \mathrm{a}$, and $\mathrm{C}-9 \mathrm{a}$ of $\mathbf{5 a}, \mathbf{b}$ were calculated from the corresponding data of 8 (Figure 3). Greater effects should be induced by the isopropyl group, which is known to produce a downfield shift of $\Delta \delta=20.2$ or $21.4 \mathrm{ppm}$ for the ipso carbon in benzene or pyridine, respectively. ${ }^{25}$ An average value of $\Delta \delta=20.8 \mathrm{ppm}$ was used in the calculation of $\delta(\mathbf{C}-7)$ in $\mathbf{5 a}$ and $\delta(\mathrm{C}-8)$ of $\mathbf{5 b}$. Furthermore, isopropyl groups cause moderate shielding effects for carbon atoms in "ortho" position, for example, $\Delta \delta=2.2 \mathrm{ppm}$ in benzene and $\Delta \delta=1.8 \mathrm{ppm}$ in pyridine. ${ }^{25}$ Thus, an upfield shift of $\Delta \delta=2.0$ ppm was included when $\delta(\mathbf{C}-8)$ of $\mathbf{5 a}$ and $\delta(\mathbf{C}-7)$ of $\mathbf{5 b}$ were calculated from the corresponding data of $\mathbf{8}$. Finally, isopropyl groups also induce a small shielding effect for protons in "ortho" position $\left(\Delta \delta=0.13 \mathrm{ppm}\right.$ in the case of cumene). ${ }^{25}$ This is taken into consideration for $\delta(\mathrm{H}-8)$ of $\mathbf{5 a}$ and $\delta(\mathrm{H}-7)$ of $\mathbf{5 b}$ (Figure 3). The calculated results exclude $\mathbf{5 b}$ as a potential candidate, but the NMR data estimated for $\mathbf{5 a}$ are nearly identical with those measured for acremolin, which should no longer be characterized by structure $\mathbf{4}$. Both structures, $\mathbf{4}$ and $\mathbf{5 a}$, can easily be distinguished when the coupling constants ${ }^{1} J\left(\mathrm{C}-1^{1} / \mathrm{H}-1^{\prime}\right)$ of $4^{26}$ or ${ }^{1} J(\mathrm{C}-8 / \mathrm{H}-8)$ of $\mathbf{5 a}$ are known. In the case of $\mathbf{5 a}$, the value of ${ }^{1} J$ should be about $190 \mathrm{~Hz}$, which is quite typical for ${ }^{1} J(\mathrm{C}-4 / \mathrm{H}-4)$ or 
${ }^{1} J(\mathrm{C}-5 / \mathrm{H}-5)$ of imidazoles. ${ }^{27}$ For example, ${ }^{1} J(\mathrm{C}-7 / \mathrm{H}-7)=191 \mathrm{~Hz}$ was measured for $8{ }^{23 b}$ On the other hand, ${ }^{1} J\left({ }^{13} \mathrm{C},{ }^{1} \mathrm{H}\right)$ is expected to be greater than $230 \mathrm{~Hz}$ for $1 \mathrm{H}$-azirines such as $\mathbf{4}$ (compare also to ${ }^{1} \mathrm{~J}(\mathrm{C}-3 / \mathrm{H}-3)$ in $2 \mathrm{H}$-azirines $\left.{ }^{28}\right){ }^{27}$

In summary, it has been demonstrated now that there is no necessity to assign the very unlikely antiaromatic structure $\mathbf{4}$ to the natural product acremolin. Instead, this compound shows stability and spectroscopic data, which are highly compatible with the structure of $\mathrm{N}^{2}, 3$-ethenoguanine 5a. Thus, $1 \mathrm{H}$-azirines keep their classification as very short-lived intermediates.

\section{Acknowledgments}

The author thanks Dr. A. Ihle for assistance with the manuscript. This is a post-peer-review version from Tetrahedron Letters, 53, K. Banert, Acremolin, a stable natural product with an antiaromatic $1 \mathrm{H}$-azirine moiety? A structural reorientation, 6443-6445, 2012, with permission from Elsevier, self-archived on http://monarch.qucosa.de in 2014. The definitive publisherauthenticated version is available online at: http://dx.doi.org/10.1016/j.tetlet.2012.09.061 - See more at: http://www.sciencedirect.com/science/journal/00404039.

\section{References and Notes}

1. Reviews on $1 H$-azirines and $2 H$-azirines: (a) Backes, J. In Houben-Weyl, Vol. E16c; Klamann, D., Ed.; Thieme: Stuttgart, 1992, pp 321-369; (b) Nair, V. In The Chemistry of Heterocyclic Compounds, Small-Ring Heterocycles, Vol. 42, Part 1; Hassner, A., Ed.; Wiley: New York, 1983, pp 215-332; (c) Pearson, W. H.; Lian, B. W.; Bergmeier, S. C. In Comprehensive Heterocyclic Chemistry II, Vol. 1A; Padwa, A., Ed.; Pergamon: New York, 1996, pp 1-60; (d) Palacios, F.; Ochoa de Retana, A. N.; Martinez de Marigorta, E.; de Los Santos, J. M. Eur. J. Org. Chem. 2001, 2401-2414; (e) Gilchrist, T. L. Aldrichimica Acta 2001, 34, 51-55; (f) Rai, K. M. L.; Hassner, A. In Advances in Strained and Interesting Organic Molecules, Vol. 8; Halton, B., Ed.; Jai Press: Greenwich, 2000, pp 187-257; (g) Fowler, F. W. Adv. Heterocycl. Chem. 1971, 13, 45-76; (h) Wentrup, C. $A d v$. Heterocycl. Chem. 1981, 28, 231-361.

2. a) Miller, T. W.; Tristram, E. W.; Wolf, F. J. J. Antibiot. 1971, 24, 48-50; (b) Molinski, T. F.; Ireland, C. M. J. Org. Chem. 1988, 53, 2103-2105; (c) Salomon, C. E.; Williams, D. H.; Faulkner, D. J. J. Nat. Prod. 1995, 58, 1463-1466; (d) Stapley, E. O.; Hendlin, D.; Jackson, M.; Miller, A. K.; Hernandez, S.; Mata, J. M. J. Antibiot. 1971, 24, 42-47; (e) Davis, F. A.; Reddy, G. V.; Liu, H. J. Am. Chem. Soc. 1995 , 117, 3651-3652; (f) Davis, F. A.; Liu, H.; Liang, C.-H.; Reddy, G. V.; Zhang, Y.; Fang, T.; Titus, D. D. J. Org. Chem. 1999, 64, 8929-8935.

3. Regitz, M.; Arnold, B.; Danion, D.; Schubert, H.; Fusser, G. Bull. Soc. Chim. Belg. 1981, 90, 615-631.

4. (a) Jacox, M. E.; Milligan, D. E. J. Am. Chem. Soc. 1963, 85, 278-282; (b) Kodama, S. J. Phys. Chem. 1988, 92, 50195024

5. Maier, G.; Schmidt, C.; Reisenauer, H. P.; Endlein, E.; Becker, D.; Eckwert, J.; Hess, B. A.; Schaad, L. J. Chem. Ber. 1993, 126, 2337-2352.

6. (a) Fowler, F. W.; Hassner, A. J. Am. Chem. Soc. 1968, 90, 2875-2881; (b) Anderson, D. J.; Gilchrist, T. L.; Rees, C. W. Chem. Commun. 1969, 147; (c) Gilchrist, T. L.; Gymer, G. E.; Rees, C. W. Chem. Commun. 1971, 1519-1520; (d) Anderson, D. J.; Gilchrist, T. L.; Gymer, G. E.; Rees, C. W. J. Chem. Soc., Perkin Trans. 1 1973, 550-555; (e) Gilchrist, T. L.; Gymer, G. E.; Rees, C. W. J. Chem. Soc., Perkin Trans. 1 1973, 555-561; (f) Atkinson, R. S.; Grimshire, M. J. J. Chem. Soc., Perkin Trans. 1 1986, 1215-1224.

7. Gilchrist, T. L.; Gymer, G. E.; Rees, C. W. J. Chem. Soc., Perkin Trans. 1 1975, 1-8.
8. (a) Mitchell, G.; Rees, C. W. J. Chem. Soc., Chem. Commun. 1986, 399-401; (b) Mitchell, G.; Rees, C. W. J. Chem. Soc., Perkin Trans. 1 1987, 413-422.

9. (a) Huisgen, R.; Blaschke, H. Chem. Ber. 1965, 98, 29852997; (b) Meinwald, J.; Aue, D. H. J. Am. Chem. Soc. 1966, $88,2849-2850$

10. Gilchrist, T. L.; Gymer, G. E.; Rees, C. W. J. Chem. Soc., Chem. Commun. 1973, 835-836.

11. Gilchrist, T. L.; Rees, C. W.; Thomas, C. J. Chem. Soc., Perkin Trans. 1 1975, 8-11.

12. (a) Wentrup, C.; Crow, W. D. Tetrahedron 1970, 26, 39653981; (b) Thétaz, C.; Wentrup, C. J. Am. Chem. Soc. 1976, 98 , 1258-1259.

13. Wentrup, C. Helv. Chim. Acta 1972, 55, 1613-1617.

14. (a) Clark, D. T. Theoret. Chim. Acta (Berl.) 1969, 15, 225234; (b) Hopkinson, A. C.; Lien, M. H.; Yates, K.; Csizmadia, I. G. Int. J. Quantum Chem. 1977, 12, 355-368; (c) Bock, H.; Dammel, R. Chem. Ber. 1987, 120, 1971-1985; (d) Alcami, M.; Mó, O.; Yáñez, M. J. Am. Chem. Soc. 1993, 115, 11074 11083; (e) Lathan, W. A.; Radom, L.; Hariharan, P. C.; Hehre, W. J.; Pople, J. A. Top. Curr. Chem. 1973, 40, 1-45.

15. (a) Mó, O.; Yáñez, M.; Elguero, J. J. Mol. Struct. (Theochem) 1989, 201, 17-37; (b) Byun, Y.-G.; Saebo, S.; Pittman, C. U. J. Am. Chem. Soc. 1991, 113, 3689-3696; (c) Malar, E. J. P. Tetrahedron 1996, 52, 4709-4718.

16. (a) Budzelaar, P. H. M.; Cremer, D.; Wallasch, M.; Würthwein, E.-U.; Schleyer, P. v. R. J. Am. Chem. Soc. 1987, 109, 6290-6299; (b) Alcami, M.; de Paz, J. L. G.; Yáñez, M. J. Comp. Chem. 1989, 10, 468-478.

17. (a) Würthwein, E.-U. J. Org. Chem. 1984, 49, 2971-2978; (b) Mó, O.; de Paz, J. L. G.; Yáñez, M. J. Phys. Chem. 1987, 91, 6484-6490.

18. Č́rsky, P.; Hess, B. A.; Schaad, L. J. J. Am. Chem. Soc. 1983, 105, 396-402.

19. Julianti, E.; Oh, H.; Lee, H.-S.; Oh, D.-C.; Oh, K.-B.; Shin, J. Tetrahedron Letters 2012, 53, 2885-2886.

20. The numbering for $\mathrm{H}-1^{\prime} / \mathrm{H}-2^{\prime}$ and $\mathrm{C}-1^{\prime} / \mathrm{C}-2^{\prime}$ is borrowed from Shin et al. ${ }^{19}$ although it is not logical to give the substituted carbon atom a higher number than the unsubstituted carbon.

21. (a) Günther, H. NMR Spektroskopie, 3rd ed., Thieme: Stuttgart 1992, pp. 83-91; (b) Balci, M. Basic ${ }^{1} H_{-}{ }^{13} C-N M R-$ Spectroscopy, Elsevier: Amsterdam, 2005, pp. 47-48.

22. Hesse, M.; Meier, H.; Zeeh, B. Spektroskopische Methoden in der organischen Chemie, 6th ed., Thieme: Stuttgart, 2002, pp. 169-170.

23. (a) Fedtke, N.; Boucheron, J. A.; Turner, M. J.; Swenberg, J. A. Carcinogenesis 1990, 11, 1279-1285; (b) Guengerich, F. P.; Persmark, M.; Humphreys, W. G. Chem. Res. Toxicol. 1993, 6, 635-648; (c) Kuśmierek, J. T.; Jensen, D. E.; Spengler, S. J.; Stolarski, R.; Singer, B. J. Org. Chem. 1987, 52, 2374-2378; (d) Lee, S. H.; Oe, T.; Blair, I. A. Chem. Res. Toxicol. 2002, 15, 300-304; (e) Sattsangi, P. D.; Leonard, N. J.; Frihart, C. R. J. Org. Chem. 1977, 42, 3292-3296.

24. Still, I. W. J.; Plavac, N.; McKinnon, D. M.; Chauhan, M. S. Can. J. Chem. 1978, 56, 725-729.

25. Pretsch, E.; Seibl, J.; Simon, W.; Clerc, T. Tabellen zur Strukturaufklärung organischer Verbindungen mit spektroskopischen Methoden, 3rd ed., Springer: Berlin, 1990.

26. Unfortunately, Shin et al. ${ }^{19}$ did not give values for ${ }^{1} J\left({ }^{13} \mathrm{C},{ }^{1} \mathrm{H}\right)$, especially for the ${ }^{13} \mathrm{C}$ NMR signal of acremolin with $\delta=$ 103.1.

27. Kalinowski, H.-O.; Berger, S.; Braun, S. ${ }^{13} C-N M R-$ Spektroskopie, Thieme: Stuttgart, 1984.

28. (a) Isomura, K.; Taniguchi, H.; Mishima, M.; Fujio, M.; Tsuno, Y. Org. Magnet. Reson. 1977, 9, 559-562; (b) Guillemin, J.-C.; Denis, J.-M.; Lasne, M.-C.; Ripoll, J.-L. Tetrahedron 1988, 44, 4447-4455. 


\section{Graphical Abstract}

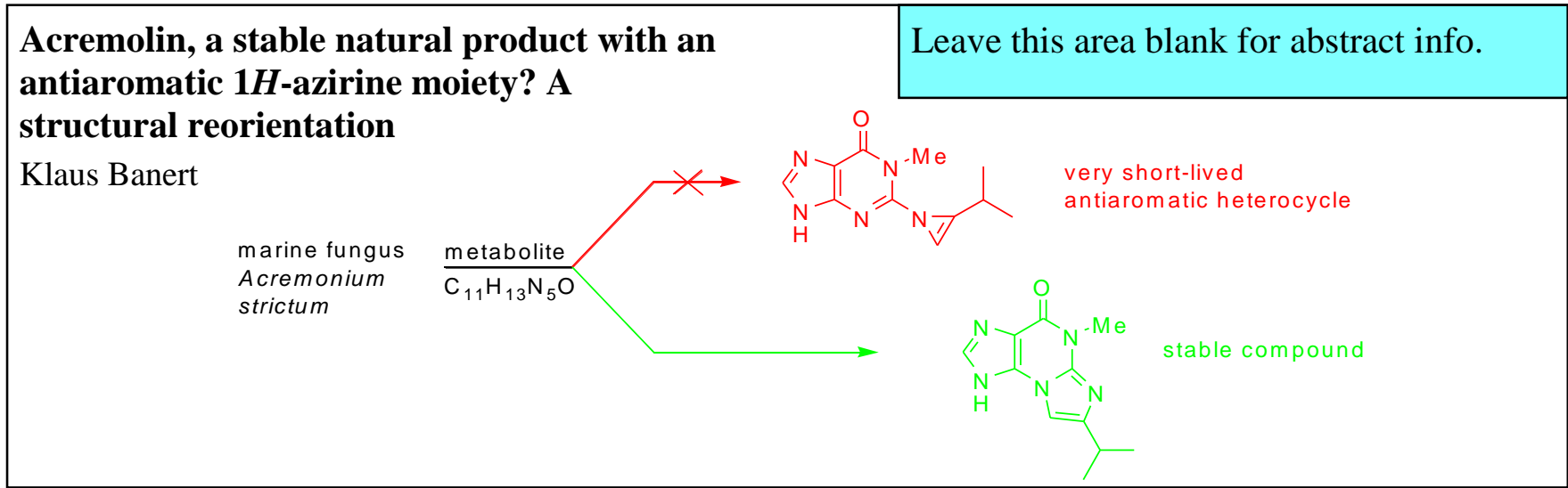

